\title{
Exploring The Efficiency And Effectiveness Of Employment Policy Program For Vulnerable People
}

Eun Joo Lee, KDI School of Public Policy and Management, Republic of Korea Yoon C. Cho, Ph.D., KDI School of Public Policy and Management, Republic of Korea

\begin{abstract}
The purpose of this study is to investigate the relationship between efficiency and effectiveness of employment policy programs for vulnerable people. The study conducted both qualitative and quantitative research. For qualitative research, in-depth interviews were conducted in order to examine the insights of experts in the field regarding the needs, expectations and attitudes of vulnerable people towards jobs. Quantitative research is designed for the efficiency and effectiveness of main functions including analyzing and defining targets; setting program plans; operating and delivering service; and program improvement. The results of the study indicate that the appropriate selection of target beneficiaries; attractiveness of hiring entities, well-prepared program content; funding; campaign; counselling; training; and tailored and integrated services are relevant to the efficiencies of the major functions of the program. The study provides policy implications for the application of innovative welfare service delivery and the creation of eligible labor markets for vulnerable people.
\end{abstract}

Keywords: Employment; Efficiency; Effectiveness; Vulnerable People

\section{INTRODUCTION}

\subsection{Objective of the Study}

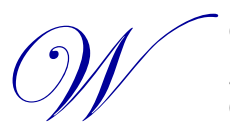

elfare populism refers to political ideas and activities that provide what people ask for and intends to garner public support from ordinary people (Cambridge University Press, 2015). According to Caplan (2001) refers to how all politicians behave and implies that they should consider what the public wants, while the problem is how they abuse their promises without considering expenses or current regulation (Yang, 2013). Thus the concept of welfare populism urges one to choose between selective welfare and common (i.e., universal) welfare. Giddens (2013) contends that well-funded and planned social welfare improvement could make a more stable society, despite initial criticism.

If the welfare system is not settled as dispensed welfare but as productive welfare, the sharp objections might no longer be valid (Blair, 1998). However, there are still many contentious matters, such as how to operate productive welfare policies as effective policies in a way that makes its beneficiaries financially independent (Rector, 2012; Jeong, 2010; Moreira, 2002). According to the OECD (2012), welfare states spent nearly $2 \%$ of GDP on public expenditure and labor market programs such as training, incentive, start-ups, direct job creation, etc. How do policies for the poor or vulnerable groups depend on governmental political agenda-setting? Elder and Cobb (1984) explain the following types of agenda setting: (i) the outside initiative model with external group proposal; (ii) the mobilization model initiated by political decision-makers; and (iii) the inside access model from external groups who are able to access high officials or decision makers. Lee and Lee (2013) examine the types of political agenda and conclude that most of the policies for poor people in some countries follow the mobilization model, whilst those in the U.S. primarily follow the outside initiative model with political pluralism. The study raises the questions of how influential the government's leading policies are in certain political environments and how governmental initiatives could be implemented more efficiently and effectively. 
This study contends that the employment policy program for vulnerable people with workability aims at self-reliance; social and financial independence; and social inclusion, rather than driving this group into a competitive market with mandatory working condition in order to decrease welfare expenditures. This paper investigates employment policy programs as one of the alternatives for vulnerable people. Despite the right to work being entrenched in the constitutions of a variety of countries, programs for vulnerable people seem not to work both efficiently and effectively. The purpose of this study is to investigate the relationship between government-driven employment policies and their impact on socially vulnerable groups of people. The following research questions will be investigated: i) how to improve the efficiency of the program in analyzing job seekers amongst vulnerable people and hiring entities; ii) how to offer selective supports for capable job seekers related to the program efficiency; iii) how to increase program efficiency, including operating bodies, program contents, funding, campaign and promotion, operation processes, and evaluation criteria; iv) how to improve program efficiency if the program includes registration and consulting, and continues with relevant training or education cases are closed with matching, followup and evaluation; v) how the tailored program contributes to the efficiency of employment program with particularity; vi) which elements of programs have an impact on the overall efficiency of the program such as analyzing, planning and operations, and an improvement process; vii) how closely related are the efficiency and the effectiveness of the program; and viii) without budget increases, does the employment policy program contribute to providing sustainable jobs to vulnerable people?

\section{LITERATURE REVIEW}

\subsection{Definition of Vulnerable People}

Vulnerability was defined as a criterion for evaluating the risks of impoverishment from physical and social capital, as well as aspect of welfare status such as nutrition, education, etc. (Bang \& Kang, 2012). Noh (2006) stated that the concept of a vulnerable group may be widely defined as a group of people who are under severe limits to their economic and social participation. According to Bang and Kang (2012), the objective definition of vulnerable group and the policies for employment and welfare include vulnerable groups that are individuals or classes, who have difficulty maintaining their current economic condition under socially and economically weak positions, who experience unexpected events during the process of employment and economic activities; or are at social risk during their lifetimes. Various studies attempt to define "vulnerable people", but most of these studies admit the difficulties of arriving at a firm definition.

Levine (2008) mentioned that U.S. federal regulations recognize "particularly vulnerable" and "economically disadvantaged" groups, as well as categories such as children, prisoners, pregnant women, foetuses and neonates, including those who literally live in poverty. Levine (2008) also described vulnerable people as the typical groups "recognized as vulnerable" such as the poor person subjects to discrimination, intolerance, subordination and stigma, including those who are politically marginalized, disenfranchised, and denied human rights. Based on Flaskerud and Winslow's (1998) wrote, the definition of vulnerable people refers to social groups that experience limited resources and it is therefore an appropriate guiding principle in bioethics. Ruof (2004) mentioned that difficulties in defining vulnerability have prompted discourse surrounding its utility as a qualifying factor in the allocation of resources and its appropriateness as a guiding principle.

\subsection{Different Groups of Vulnerable People}

This study reviewed the type, status, satisfaction and impact of the employment program based on categories of vulnerable people such as the aged, disabled, single parents and the homeless.

The aged group: The concept of the aged in developed society has changed from people who are old, weak and dependent on benefits to those living longer and healthier lives and capable of being more productive and less dependent (Choi \& Dinse, 2006). Consequently, a social intervention in the labor market encourages training social workers; conducting early childhood and elementary schools, providing intergenerational program and assisting older adults with employment, volunteering and health care (Choi \& Dinse, 2006). An active aging strategy should be comprehensive, flexible, preventive, and participatory at the individual and societal levels and linked with employment, health, social protections, social inclusion, transport, education, and mutual support (Walker, 2002; 2006). 
Disabled group: What makes it difficult for the disabled to work or actively participate in employment? Patrick (2011) studies three elements: barriers to work, conditionality itself and ideas of the welfare contract between citizens and the state. Shier, Ghaham and Jones (2009) found that the barriers include both individual and societal conditions such as transportation, lack of support networks, self-esteem, past influences and disability. This study also intends to provide the respondents' perspectives on how mental, physical, physiological and intellectual disabilities are influential in them securing or maintaining employment.

Single parents: Thomson, Hanson and McLanahan (1994) found that single-mother families have significant economic disadvantages for children, but that the effects of income on parental support are not significant. With engagement in welfare-to-work, many single parents are unable to provide adequate social support and continually struggling in impoverished circumstances (Cook, 2012). Stewart (2009) mentioned that post-secondary qualifications and advanced or vocational skills encourage comparably faster wage progression; it is therefore suggested that policies should consider sustainability and progression in the initial stages of employment of single mothers, and should take another approach to promote the employment working for mothers who stay at home.

Homeless people: Nam (2012) listed the possible reasons for a person becoming homeless as low income, deprivation, family dissolution, long-term unemployment, bankruptcy, low education, domestic violence, mental illness, alcohol and drug addiction, and personal preference. Radey and Wilkins (2011) posit hat homeless job seekers with significant physical or mental health problems believe that they can overcome their problems and get employment, whereas service providers take strongly negative attitudes toward this prospect. Service providers should realize that better financial assistance and other concrete services are important to improve the capabilities of homeless people (Lindsey, 1998).

\subsection{States of Welfare}

Product welfare is a welfare policy for realizing social needs to improve the quality of life by growing in economic capability and developed democracy while at the same time, it is a human development policy to support basic livelihood, security and social insurance, which improves life quality and growth potential with social and financial independence and human capital progress through education and training (Yang, Lee, Lee, Lee, \& Cho, 2000). EspingAnderson (1990) classified three welfare states by regime-types: liberal welfare states, corporatist welfare states, and social democratic states. Dostal (2008) clarified the policy instrument as three different types of policy instruments: active labor market policy (ALMP), market workfare, and make-work workfare. Jagannathan and Camasso (2005) compare the following different types of welfare-to-work programs: labor forced attachment (LFA), human capital investment (HCI) and a mixed strategy.

Walker (2002) recommended an active strategy linked with employment, health, social protections, social inclusion, transportation and education, amongst others, at both the levels of the individual and of societies. Evers and Guillenard (2012) stated that new institutional links have been established between social policy and the employment system, and at the same time, between welfare bureaucracies and their target groups. Hoefer and Midgley (2006) focused on the inter-linkage of activation program and social work, showing the interests of further policy moves. Previous studies (Bode \& Sandvin, 2012; Evers \& Guillemard, 2012) conclude that the movement towards workfare and activation from sociological perspectives need to pay more attention to the roles of social intervention including social work.

\section{THEORETICAL BACKGROUND}

Mihaiu, Opreana, and Cristescu (2010) argue that efficiency can be achieved under the conditions of maximizing the results of an action about the resources used. Mihaiu, Opreana, \& Cristescu (2010) also explain that efficiency and effectiveness are the relationships between inputs (i.e. all resources entering into the production of public sector activities in monetary and non-monetary terms); outputs, and outcomes (i.e. political agendas and long-term expectation of the output). McCain and Shorten (2002) claimed that efficiency and effectiveness are difficult to measure, analyze and compare partly because operation is complex and vary substantially from one to another. Lynn and Robichau (2013) studied governance and organizational effectiveness based on a multi-governance framework, focusing on the analysis and design of public policies, as well as the measurement and evaluation of governing institutions, agencies, and programs. Heinrich (2002) studied outcomes-based performance management at all 
government levels, particularly in federal job-training programs. The theory of public sector performance as a once off multilevel model is related to all aspects of program operations including contracting, participation selection and service delivery (Heinrich, 2002).

\section{HYPOTHESES DEVELOPMENT}

The purpose of this study is to investigate the efficiency and effectiveness of employment policy programs for vulnerable people. This study states that policy programs are developed based on four major functions, namely; i) analyzing and redefining the target group; ii) setting a program plan; iii) operating and delivering services; and iv) improving the policy program. According Blalock's (1999) research on significant elements in an ideal policy process, strategic planning, visionary management and evaluation research would seem to be integral and equally important parts (Blalock, 1999). Greve (2009) mentioned that government policy plans tend to highlight the role of disabled people about targeted initiatives rather than mainstream policies. Improvement requires supportive organizational structures and clearly defined professional roles between planners, managers, and evaluators through the course of their activities (Blalock, 1999). This study proposes the four major functions as independent variables (Figure 1).

Figure 1. Framework for the Efficiencies and Effectiveness of Employment Policy Programs

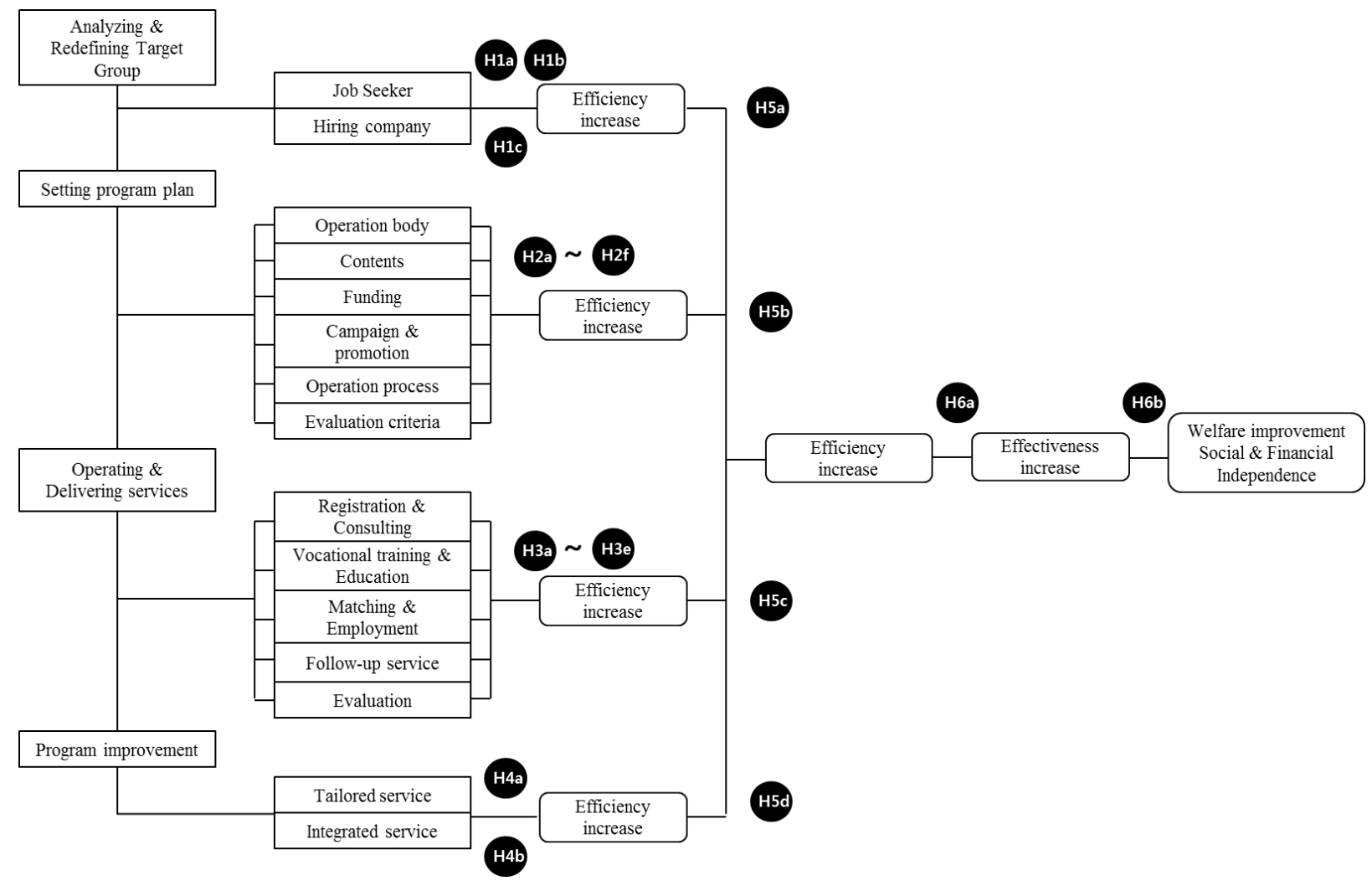

Under the main four functions, there are several subordinate activities and these subordinate activities would be perceived as being more detailed in the program management regarding increases in the efficiency of the four major variables $(\mathrm{H} 1 \mathrm{a} \sim \mathrm{H} 4 \mathrm{~b})$. This study also hypothesized how each major variable impact on the overall efficiency of the employment policy program $(\mathrm{H} 5 \mathrm{a} \sim \mathrm{H} 5 \mathrm{~d})$ and how the overall efficiency can influence the effectiveness of the program in making vulnerable people financially independent and self-reliant, as well as socially inclusive (H6a H6b). 


\subsection{Analyzing and Refining the Target Group}

At the stage of analyzing and refining the target group, the process would increase the efficiency of an employment policy program by clarifying targeted people. This study assumes two subordinate actors measure the efficiency of the first main groups: i) vulnerable people as job seekers and ii) hiring companies as job providers. Engau and Hoffmann (2009) state that the early stages of the policy-making process could enable them to operate in a more target-oriented manner, allow for more efficient policy implementation and increase a regulation's effectiveness (Engau \& Hoffmann, 2009). This study hypothesizes that knowing each category of vulnerable people would help efficient policy programs to deliver benefits to the right targets and also help to attract job providers and make them feel more confident in hiring vulnerable people. Ruof (2004) emphasizes the difficulties in defining vulnerable people regarding the appropriate allocation of resources. Furthermore, public and employer perceptions have a strong effect on the employment continuity of vulnerable people in the workplace, and employers and employees have different attitudes toward vulnerabilities (Shier, Ghaham, \& Jones, 2009; Radey \& Wilkins, 2011). This study hypothesized that the effects of defining and analyzing vulnerable people on efficiency and the impact of hiring entities on employment programs would be critical.

H1a: Defining and analyzing vulnerable people would increase efficiency in analyzing the targets of the employment program.

H1b: Selective support of vulnerable people meeting a certain level of qualification would increase efficiency in analyzing and defining the targets of the employment program.

H1c: As an active agent of an employment program, more hiring companies increase their efficiency in analyzing and defining the targets of the employment program.

\subsection{Policy Program Plan}

The second main factor is setting the program plan. After analyzing and redefining the target group, a plan on how to deliver the program must be developed. Wildavsky (1973) claims that planning is an attempt to control the consequences of certain actions. With government programs such as senior citizen work projects (Hwang, et al., 2007), park projects (Song, 2013), and Experiential Environmental Education Programs (Lee, Kim, Lee, Kim, Kim, and Kim, 2006) and amongst others, it is apparent that the subordinate elements of the program plan are important to leading a successful program. Planning comprises of six sub-activities: operating body; program contents; funding; campaign and promotion of the policy; operating process setting; and evaluation criteria. The trend is that policy programs are increasingly operated by agencies, and identification can improve the program's performance (Pollit, Bathgate, Caulfield, Smullen, \& Talbot, 2001). This study addresses who operates the program; what the program contents are; how much funds are provided; which promotions and campaigns are effective; which operation process will deliver the services to the beneficiaries; and how the results and benefits are evaluated. This study also hypothesizes how subordinate activities such as operating bodies (service providers), program content, funding, campaign and promotion, operation process, and evaluation criteria and supervision affect the efficiency of the program plan. This study hypothesizes about the overall efficiency of the program and its effectiveness for the beneficiaries (H2a $\sim \mathrm{H} 2 \mathrm{f})$.

H2a: Operating bodies (i.e., service providers) would increase efficiency in the employment program.

H2b: Contents of programs and guide to operation would increase efficiency in setting program plans for the employment program.

H2c: Funding (i.e., budget support) would increase efficiency in setting program plans for the employment program.

H2d: Campaign and promotion would increase efficiency in setting program plans for the employment program.

H2e: The operation process would increase efficiency in setting program plans for the employment program.

H2f: Evaluation criteria and supervision would increase efficiency in setting program plans for the employment program. 


\subsection{Policy Program Operation}

The study measures how each activity in the program operation would improve the efficiency of the operation in general. Operation and delivery service are followed with five proceeding activities from registration and consulting vulnerable people who are willing to participate in work programs, to evaluation of the programs. Sweet (2001) states that developments in education policy, labor market policy and welfare policy indicate an important role for counseling services (Sweet, 2001). From the counseling session, prior needs can be realized, and this would increase the program efficiency (H3a). Vocational training and other job-related educations are also essential for job-seekers amongst vulnerable people because they are often uneducated and physically weak. Regarding public employment policy, education and training are the major approaches favored by the government (Taylor, 1994). To overcome vulnerability, training and education are required to achieve the qualification of employability (Yates \& Roulstone, 2013). This study hypothesized how vocational training and job-related education can increase efficiency in the program operation for vulnerable people (H3b). During the matching, the low self-esteemed candidate can receive tips for writing a resume and having successful job interviews. Before the job matching process, the activities should be preparation activities. O'Higgins (2001) posits that job search assistance improves the matching of jobs with applicants. Therefore, this matching is a central activity in the entire employment program operation. Consequently, this study hypothesized how the good practice of matching can increase the efficacy of a program's operation. (H3c). After hiring, the follow-up service would help hired vulnerable people maintain and develop their work skills, even moving up to better jobs. This study hypothesized that the subjects of the follow-ups are beneficiaries, and the process continues to discover further needs and difficulties that vulnerable people face since becoming employed (H3d). Furthermore, monitoring will realize whether or not the program operates based on the guidelines, and evaluation suggests program improvement by recognizing which programs perform successfully and the reasons for their success (O'Higgins 2001). This study hypothesizes about the relationship between evaluation and the efficiency of program operation. (H3e)

H3a: Registration and consulting vulnerable people would increase efficiency in the operating and delivery service of the employment program.

H3b: Vocational training and job-related education would increase efficiency in the operating and delivery service of the employment program.

H3c: Matching service would increase efficiency in the operating and delivery service of the employment program.

H3d: Follow-up service would increase efficiency in the operating and delivery service of the employment program.

H3e: Evaluation would increase efficiency in the operating and delivery service of the employment program.

\subsection{Policy Program Improvement}

As a developed model of the welfare program, this study accepts the tailored and integrated welfare programs from previous studies (Choi \& Jang, 2007; Jung, et al., 2013). The tailored and integrated welfare programs are linked with employment programs and other welfare program because employment policy programs in themselves cannot be the fundamental solution for vulnerable people to overcome their difficulties and to become independent. For example, many single parents would like to work, but it is physically difficult to balance work and parenting. This study hypothesized about the efficiency of a program for target-oriented services (H4a) and integrated services with other welfare programs to bring effective solutions (H4b).

H4a: Tailored (target-oriented) service would increase efficiency in the program improvement of the employment program.

H4b: Integrated (linked between employment program and other welfare program) service would increase efficiency in the program improvement of the employment program. 


\subsection{Overall Assessment}

This study is designed to discover how each subordinate element increases the efficiency of the four main factors at the first tier, as well as to realize which major factor would be more related to the overall efficiency of the program. Furthermore, the study explores how to increase the employment program's overall efficiency without additional funds, particularly for a vulnerable population (H5a $\sim \mathrm{H} 5 \mathrm{~d}$ ). This study hypothesized about the relationship between efficiency and effectiveness (H6a) and impact on welfare and financial and social independence of vulnerable people (H6b), because the fundamental idea behind the research was that increasing the efficiency of the employment program would more effectively improve the social welfare of vulnerable people and their chances of financial independence despite of limited resources. Newman, Glendinning and Hughes (2008) study explored improving the organization, delivery and efficiency of service for the social care program as a whole. Similarly, it looks into the program as a whole from target analysis, planning and operation to improvements of the program and the relationship with program efficiency and effectiveness.

H5a: Analyzing and defining target would increase efficiency in the overall employment program, without additional budget support.

H5b: Setting program plans would increase efficiency in the overall employment program, without additional budget support.

H5c: Operating and delivering service would increase efficiency in the overall employment program, without additional budget support.

H5d: Program improvement to the tailored and integrated service would increase efficiency in the overall employment program, without additional budget support.

H6a: Before immediate budget increases or social welfare expansion, improving the efficiencies of the current employment the program would increase the effectiveness of the program for its beneficiaries.

H6b: Increases in the effectiveness of the employment program would help social welfare improvement and the financial and social independence of vulnerable populations.

\section{METHODOLOGY}

\subsection{Qualitative Research}

\subsubsection{Methodologies for Qualitative Research}

To collect vivid voices from the field, this study conducts qualitative research. Amongst many other qualitative research methods, this study applied in-depth interviews with field experts. Seidman (2013) states that interviewing is a powerful way to gain insight into educational and other important social issues through understanding the experience of the individuals whose lives reflect those issues. The interviews were held with seven interviewees: five social workers from welfare facilities for released prisoners; single parents; senior citizens; the homeless; the disabled; one social welfare staff member in charge of a community center; and one general manager of the social enterprise. This study selected field social workers instead of vulnerable people as interviewees for the following reasons: i) an extremely low possibility of recruitment of vulnerable people for interviews; ii) an inability to getting valid responses regarding questions of efficiency and effectiveness of policy programs; and iii) the better knowledge and experience of field workers. The interviews took about one hour. The interviews were designed such that interviewees mainly led the entire interview in order to acquire real abundant cases. To fully concentrate, the interviewer asked if he could use a voice recorder instead of note-taking with a promise not to make any part of the interview public. 


\subsubsection{Findings from Qualitative Research}

The in-depth interviews allow for learning about the contents of programs, the uniqueness of entities, field experience from experts, as well as difficulties and improvement measures. Table 1 summarizes the distinctive items from the indepth interviews.

Table 1. Summary of the Qualitative Research Result

\begin{tabular}{|c|c|c|c|c|c|c|c|c|c|}
\hline No. & $\begin{array}{l}\text { Target } \\
\text { Group }\end{array}$ & Interviewee & Type & Funding & $\begin{array}{l}\text { Consulting/ } \\
\text { Counselling } \\
\end{array}$ & Training & Matching & Tailored & Integrated \\
\hline 1 & Aged & $\begin{array}{l}\text { Y.C.S } \\
\text { (A) }\end{array}$ & Consigned & Public & $\begin{array}{l}\text { Individual chart } \\
\text { Attitude, needs }\end{array}$ & $\begin{array}{l}\text { Training } \\
\text { Tips for } \\
\text { resume \& } \\
\text { interview }\end{array}$ & $\begin{array}{c}\text { Manual job } \\
\text { Strong } \\
\text { candidate first }\end{array}$ & $\begin{array}{l}\text { Actual } \\
\text { needs }\end{array}$ & $\begin{array}{c}\text { service } \\
\text { Information }\end{array}$ \\
\hline \multirow[b]{2}{*}{2} & \multirow[b]{2}{*}{ Disabled } & \multirow[b]{2}{*}{$\begin{array}{l}\text { C.J.E } \\
\text { (B) }\end{array}$} & \multirow[b]{2}{*}{$\begin{array}{l}\text { Consigned } \\
\text { Individual }\end{array}$} & \multirow{2}{*}{$\begin{array}{l}\text { Public } \\
\text { Private } \\
\text { Donation }\end{array}$} & \multirow[b]{2}{*}{$\begin{array}{l}\text { Social diagnosis } \\
\text { Individual chart }\end{array}$} & \multirow{2}{*}{$\begin{array}{l}\text { Sheltered } \\
\text { workshop } \\
\text { Adjustment } \\
\text { training }\end{array}$} & \multirow{2}{*}{$\begin{array}{l}\text { Normal } \\
\text { processing } \\
\text { Posting } \\
\text { w/job } \\
\text { coaching }\end{array}$} & $\begin{array}{c}\text { Actual } \\
\text { needs }\end{array}$ & Service \\
\hline & & & & & & & & \multicolumn{2}{|c|}{$\begin{array}{l}\text { More benefit fewer people } \\
\text { vs. } \\
\text { Less benefit more people }\end{array}$} \\
\hline \multirow[t]{2}{*}{3} & \multirow[t]{2}{*}{ Homeless } & \multirow{2}{*}{$\begin{array}{l}\text { B.J.W } \\
\text { (C) }\end{array}$} & \multirow[t]{2}{*}{ Consigned } & \multirow[t]{2}{*}{ Public } & \multirow{2}{*}{$\begin{array}{l}\text { Building trust \& } \\
\text { relationship } \\
\text { Individual chart }\end{array}$} & \multirow{2}{*}{$\begin{array}{l}\text { Introduce } \\
\text { another } \\
\text { program }\end{array}$} & \multirow{2}{*}{$\begin{array}{l}\text { Work-Net } \\
\text { Partnership }\end{array}$} & Overlapped & $\begin{array}{c}\text { Information } \\
\text { Service }\end{array}$ \\
\hline & & & & & & & & \multicolumn{2}{|c|}{ Short-term vs. Long-term } \\
\hline 4 & Single parents & $\begin{array}{l}\text { C.Y.J } \\
\text { (D) }\end{array}$ & Individual & Donation & $\begin{array}{l}\text { In-depth } \\
\text { interview } \\
\text { Home visit }\end{array}$ & $\begin{array}{l}\text { Customized } \\
\text { expert } \\
\text { consulting }\end{array}$ & $\begin{array}{l}\text { Female } \\
\text { friendly } \\
\text { sector }\end{array}$ & $\begin{array}{c}\text { Particular needs } \\
\text { (childrearing } \\
\text { and business) }\end{array}$ & Information \\
\hline 5 & $\begin{array}{l}\text { Former } \\
\text { prisoners }\end{array}$ & $\begin{array}{l}\text { S.S.W } \\
\text { (E) }\end{array}$ & Consigned & Public & Set IAP & HRD-Net & $\begin{array}{l}\text { Normal } \\
\text { processing } \\
\text { Interview w/ } \\
\text { companion } \\
\end{array}$ & Overlapped & Service \\
\hline 6 & $\begin{array}{c}\text { Disabled } \\
\text { (social } \\
\text { enterprise) }\end{array}$ & $\begin{array}{l}\text { L.J.H } \\
(\mathrm{F})\end{array}$ & $\begin{array}{l}\text { Private } \\
\text { business }\end{array}$ & $\begin{array}{l}\text { Public } \\
\text { Profit }\end{array}$ & $\begin{array}{l}\text { Individual and } \\
\text { family interview }\end{array}$ & $\begin{array}{l}\text { Iterative } \\
\text { learning }\end{array}$ & Direct hiring & $\begin{array}{c}\text { Priority } \\
\text { purchasing }\end{array}$ & $\begin{array}{l}\text { No welfare } \\
\text { related }\end{array}$ \\
\hline 7 & $\begin{array}{c}\text { Others } \\
\text { (community } \\
\text { center) }\end{array}$ & $\begin{array}{l}\text { K.Y.W } \\
\text { (G) }\end{array}$ & Public & Public & Individual chart & $\begin{array}{l}\text { Introduce } \\
\text { another } \\
\text { program }\end{array}$ & $\begin{array}{c}\text { Linked with } \\
\text { other } \\
\text { institutes } \\
\end{array}$ & required & Information \\
\hline
\end{tabular}

a. Both interviewees and related entities are described as letters $A-G$ in this chapter, instead of the initial of the interviewee's name and workplace

Each subject is recruited from a target group such as the aged; the disabled; the homeless; single parents; former prisoners; and community centers. Interviewee A mentioned that most job-seekers who come to the welfare center to get job support are mostly in financially poor, so the screening of applicants often becomes meaningless and the center provides services to all senior groups without limits on income level. Interviewee $\mathrm{G}$ states that refining and screeningeligible beneficiaries decreases dual benefits and increases the efficiency of welfare support. Interviewee $\mathrm{C}$ argued that government can identify vulnerable people, but that such identification should not have a negative impact on job prospects by branding vulnerable or poor people as such. Interviewee D addressed the needs of assistance (e.g. stable fund scheme, supporting donation, etc.) for single parents to start-up a business. Interviewee F operates a social enterprise to hire disabled people and the company as a business entity has decided to distribute their retained earning based on the articles of association and the resolution of the board of trustees, so they are more concerned with the salaries and working welfare of their employees than other welfare centers or facilities. Therefore, the diversity of funding sources leads to greater flexibility and sustainability of the program. Interviewee B explains the needs for different types of the counseling sessions, including normal counseling and social diagnosis. In light of the degree of disability of job seekers, social diagnosis tests how the disabled, particularly developmentally disordered job-seekers, can socialize in the workplace. Interviewee $\mathrm{C}$ emphasizes that it is most important to build mutually trusting relationships during the counseling. Interviewee $\mathrm{F}$ addressed the need for family interviews because there are various problems with the single disabled employees. Therefore, the hiring company and the employee, as well as the families, need to tackle these problems together. Interviewee E states the importance of family support such as a family rebuilding program that helps former prisoners with employment, social inclusion and lower recidivism rates. In sum, how training links to employment is a significant issue while many job-seekers are waiting in an extremely difficult job market. Despite the importance of job education, many job-seekers amongst vulnerable people want to get a job as soon as possible after registration because they are struggling with financial difficulties and living allowances, as 
mentioned by interviewees A and E. As interviewees A, B and E emphasize, recruiting more hiring companies is essential to lead to more employment of vulnerable people, without stereotype and prejudice.

After completing the hiring process, there are two further stages, namely follow-up and evaluation for program improvement. All interviewees agreed on the difficulties of follow-up in reality, but most of them stated that they provide as much as they can upon request. All interviewees commonly stated that the employment policy programs are 'Low efficiency and High expenditure'. However, they still strongly believe that the programs are worth keeping for two reasons: firstly, vulnerable people can become a productive population that contributes to production, consumption and tax payment: secondly, the employment policy programs still keep the welfare perspective, not pushing them into the perfectly competitive labor market. All interviewees also agree that tailored and integrated welfare is efficient and necessary. Tailored service can be structured and deliver welfare services, reflecting the real needs of beneficiaries because the needs can vary among vulnerable groups. All interviewees also indicate a problem with being a beneficiary of national basic livelihood. Many vulnerable people receive a government living allowance, but they still prefer to work to earn more money. Ironically, even possessing a business registration in itself makes them lose their right to receive the allowance, in spite of any business profit or loss. Often, the recipients are determined to remain beneficiaries of national basic livelihood rather than being employed because recovering the status of welfare recipient is extremely difficult after losing the status once and falling into poverty again. All interviewees realize the importance of restructuring the national basic livelihood scheme. For the more positive outcome of employment for vulnerable people, the interviewees suggest preferential hiring and priority purchasing. Most of these cases have a special law. However, it is often not mandatory, but simply a recommendation. Consequently, it has not been observed. Interviewee B states that disabled people need a longer time for preparation and training, so it would be good to start as early as possible at an early age. As social welfare experts, they insist that comprehensive welfare would be served in the long term. Nevertheless, considering the limited resources, it may be more practical to balance the quantity and quality of welfare. Interviewee F concludes that productive welfare can create more 'pie'. In contrast, universal welfare distributes existing the pie in pieces. From a social welfare perspective, the job market for vulnerable people should be a protected market environment.

\subsection{Quantitative Research}

\subsubsection{Methodologies for Quantitative Research}

This study also conducted quantitative research. An online survey was distributed to public officers to examine how public policymakers or enforcers perceive the efficiency and effectiveness of employment policy program for vulnerable people. One hundred and seven respondents answered the survey completely, and the response rate was $8 \%$. The respondents comprised of $70 \%$ male and $29 \%$ female. $31.8 \%$ of the respondents were above 50 years old; $37.4 \%$ were between the ages of $40-49$ years; $29.9 \%$ were between the ages of $30-39$ years; and $0.9 \%$ were in their $20 \mathrm{~s}$. As to their education, $4.7 \%$ had received a doctoral degree while $30.8 \%$ and $61.7 \%$ had a graduate degree or an undergraduate degree, respectively, and $2.8 \%$ reported that they were high school graduates. Also, all respondents are current or former public officers.

The questionnaires comprised of 31 questions based on seven categories: general questions; target analysis and definition; set the program plan, operation and delivery of service; program improvement; identification of inefficiency; overall assessment; and demographic information. The types of questions were designed with sevenpoint Likert scale questions on the matrix tables, and multiple choice questions. The questions on the 7-point Likert scale range from 1 to 7 with 1 being very disagreed and 7 being very agreed. To test the hypotheses, the study applied the regression analysis based on the research model to evaluate the links between the employment policy program and efficiency and effectiveness based on the perception of public officers. To check construct reliability, this study measures Cronbach's alpha for multi-item scales for each main constructs that serves as the basis for the survey questionnaire items. This study finds that Cronbach's alpha for analyzing and redefining the target group shows 0.622; setting program plan shows 0.858; Operating the Delivering service shows 0.885 ; and lastly Program improvement shows 0.769 . 


\subsubsection{Findings from Quantitative Research}

This study has developed hypotheses for analyzing and refining target groups $(\mathrm{H} 1 \mathrm{a} \sim \mathrm{H} 1 \mathrm{c})$, setting program plans $(\mathrm{H} 2 \mathrm{a} \sim \mathrm{H} 2 \mathrm{f})$, operating and delivering service $(\mathrm{H} 3 \mathrm{a} \sim \mathrm{H} 3 \mathrm{e})$, improving the program $(\mathrm{H} 4 \mathrm{a} \sim \mathrm{H} 4 \mathrm{~b})$, four main factors to overall efficiency (H5a $\sim \mathrm{H} 5 \mathrm{~d}$ ), and efficiency and effectiveness $(\mathrm{H} 6 \mathrm{a} \sim \mathrm{H} 6 \mathrm{~b})$, by applying regression analysis. According to target analysis and definition, the hypotheses $\mathrm{H} 1 \mathrm{a} \sim \mathrm{H} 1 \mathrm{c}$ shows the results in Table 2 below. It shows that the model for the effects of analyzing and defining target groups on efficiency is significant at the 0.01 level with $F=8.326(r$-squares $=0.195)$. Table 2 finds that the result of regression analyses for effects of policy target defining on efficiency (H1a) is not accepted, while the effects of selecting appropriate beneficiaries on efficiency (H1b) is accepted at $\alpha=0.1$ and the effects of policy target defining (H1c) on efficiency is accepted at $\alpha=0.01$.

Table 2. Summary of Effects of Redefining and Analyzing Target on Efficiency

\begin{tabular}{l|c}
\multicolumn{1}{c|}{ Variables (Independent $\rightarrow$ dependent) } & Target analysis \& define \\
\cline { 7 - 8 }$\rightarrow$ Efficiency (H1a) & Standardized Coefficient (t-value) \\
\hline Select beneficiaries $\rightarrow$ Efficiency $(\mathrm{H} 1 \mathrm{~b})$ & $0.117(1.231)$ \\
\hline Attracting more hiring companies $\rightarrow$ Efficiency (H1c) & $0.175(1.780)^{*}$ \\
${ }^{* * *}$ Significant at 0.01 level (2-tailed); ${ }^{*}$ Significant at 0.1 level (2-tailed) & $0.300(3.217)^{* * *}$
\end{tabular}

Also, during the in-depth interviews, redefining vulnerable people could be pointless for the users of the welfare center because they are struggling with financial difficulties and each center has a definite target group such as the aged or the disabled. Furthermore, most publicly funded programs have a list of qualification for beneficiaries, so the government officers determining the process of defining and analyzing would no longer increase efficiency. Selecting competitive job seekers amongst vulnerable people (Ha2) and recruiting more hiring companies (Ha3) are also supported by the results of the qualitative research.

For the testing of $\mathrm{H} 2 \mathrm{a} \sim \mathrm{H} 2 \mathrm{f}$ for the effects of setting the policy program planning on efficiency, Table 3 presents the model as significant at the 0.01 level with $F=11.077$ ( $r$-square $=0.399)$. The results of regression analysis show that the effects of program content and operation guidelines on efficiency (H2b) are significant at $\alpha=0.01$; the effects of funding on efficiency are significant at $\alpha=0.1(\mathrm{H} 2 \mathrm{c})$; and the effects of campaign and promotion on efficiency are significant at $\alpha=0.1(\mathrm{H} 2 \mathrm{~d})$. The results of the study also found that the effects of operation bodies on efficiency (H2a), the effects of operation process on efficiency (H2e), and the effects of evaluation and supervision on efficiency are not significant $(\mathrm{H} 2 \mathrm{f})$.

Table 3. Summary of Effects of Setting the Program Plan on Efficiency

\begin{tabular}{l|c}
\hline \multicolumn{1}{c}{ Variables (Independent $\rightarrow$ dependent) } & Set program plan \\
\cline { 2 - 2 } & Standardized Coefficient (t-value) \\
\hline Operating bodies $\rightarrow$ Efficiency (H2a) & $-0.027(-0.248)$ \\
\hline Contents of programs \& guide to operation $\rightarrow$ Efficiency (H2b) & $0.337(2.690)^{* * *}$ \\
\hline Funding $\rightarrow$ Efficiency (H2c) & $0.171(1.703)^{*}$ \\
\hline Campaign \& promotion $\rightarrow$ Efficiency (H2d) & $0.202(1.803)^{*}$ \\
\hline Operation process $\rightarrow$ Efficiency (H2e) & $-0.053(-0.520)$ \\
\hline Evaluation criteria \& supervision $\rightarrow$ Efficiency (H2f) & $0.142(1.550)$ \\
${ }^{* * * *}$ Significant at 0.01 level (2-tailed) ${ }^{*}$ Significant at 0.1 level (2-tailed) &
\end{tabular}

As shown in Table 4, the effects of operating and delivering services on efficiency are significant at the 0.01 level with $F=12.435(r$-square $=0.381)$. The regression analysis indicates that the effects of registration and consulting on efficiency (H3a) are significant at $\alpha=0.05$. The effects of vocational training and job-related education on efficiency (H3b) are significant at $\alpha=0.01(\mathrm{H} 3 \mathrm{~b})$. The effects of matching (H3c), follow-up (H3d) and evaluation (H3e) on efficiency are not significant. Thus, hypotheses $\mathrm{H} 3 \mathrm{a}$ and $\mathrm{H} 3 \mathrm{~b}$ are accepted, and the rest of them are rejected. According to the factors of counseling and training, the quantitative and qualitative research approaches show the same results, as both are highly effective in the program. Surprisingly, public officers do not perceive matching, follow-up, and evaluation as efficient factors of the program. Based on the contents of the interviews, there is a huge gap of expectation between job-seekers and hiring entities. Also, more job-seekers look for jobs in the competitive job markets, which have fewer positions available to vulnerable people. Evaluation is a necessary process for program the 
control and accountability but still does not count as a valid factor. The results indicate that reforms make the labor market more dynamic and accelerate the matching process by attempting to speed up the matching process between the unemployed and vacant jobs (Fahr \& Sunde 2009). Connolly and Smith (2010) mentioned that evaluation would be important in the quality practice improvements over time.

Table 4. Summary of Effects of Operating and Delivering Services on Efficiency

\begin{tabular}{l|c}
\multicolumn{2}{c}{ Table 4. Summary of Effects of Operating and Delivering Services on Efficiency } \\
\hline \multicolumn{1}{c}{ Variables (Independent $\rightarrow$ dependent) } & Operating and delivering service \\
\cline { 2 - 2 } & Standardized Coefficient $(\boldsymbol{t}$-value) \\
\hline Registrations \& consulting $\rightarrow$ Efficiency (H3a) & $0.281(2.477)^{* *}$ \\
\hline Vocational training \& job education $\rightarrow$ Efficiency (H3b) & $0.361(3.146)^{* * *}$ \\
\hline Matching service $\rightarrow$ Efficiency (H3c) & $0.078(0.661)$ \\
\hline Follow-up service $\rightarrow$ Efficiency (H3d) $\quad$ Evaluation $\rightarrow$ Efficiency (H3e) & $0.004(0.029)$ \\
\hline${ }^{* * *}$ Significant at 0.01 level (2-tailed) & $-0.039(-0.314)$ \\
\hline
\end{tabular}

Significant at 0.05 level (2-tailed)

This study hypothesized that tailored and integrated services would improve employment programs. Based on the results of regression analysis, the effects of tailored service and integrated service on efficiency are significant for policy improvement at the 0.01 level with $F=21.554$ ( $r$-square $=0.293)$. The effects of tailored service on efficiency (H4a) and integrated services on efficiency (H4b) are significant at $\alpha=0.01$. Thus, hypotheses $\mathrm{H} 4 \mathrm{a}$ and $\mathrm{H} 4 \mathrm{~b}$ are accepted (Table 5). Previous studies (Han, 2014; Lee \& Kushner, 2008) also stated that social services need to be customized based on different needs and difficulties.

Table 5. Summary of Effects of Improving Program on Efficiency

\begin{tabular}{l|c|}
\hline \multicolumn{1}{|c|}{ Variables (Independent $\rightarrow$ dependent) } & Program improvement \\
\cline { 2 - 2 } & Standardized Coefficient (t-value) \\
\hline Tailored (target-oriented) service $\rightarrow$ Efficiency (H4a) & $0.280(2.704)^{* * * *}$ \\
\hline Integrated service $\rightarrow$ Efficiency (H4b) & $0.324(3.123)^{* * *}$ \\
\hline${ }^{* * *}$ Significant at 0.01 level (2-tailed) &
\end{tabular}

The results of the analysis of variance for the overall efficiency of the program are significant at the 0.1 level with $F$ $=3.894$ ( $r$-square $=0.036)$. The results of simple regression analyses show that the effects of analyzing and defining targets on efficiency are significant at $\alpha=0.1(\mathrm{H} 5 \mathrm{a})$; the effects of setting program plans on efficiency are significant at $\alpha=0.05$ (H5b); and the effects of operating and delivering service on efficiency are significant at $\alpha=0.05$ ( $\mathrm{H} 5 \mathrm{c}$ ); the effects of tailoring and integrated service on efficiency are significant at $\alpha=0.05$ (H5d). Therefore, all hypotheses $\mathrm{H} 5 \mathrm{a} \sim \mathrm{H} 5 \mathrm{~d}$ are accepted.

Table 6. Summary of Overall Efficiency

\begin{tabular}{l|c}
\hline \multicolumn{1}{c|}{ Variables (Independent $\rightarrow$ dependent) } & $\begin{array}{c}\text { Overall assessment } \\
\text { Standardized Coefficient (t-value) }\end{array}$ \\
\hline Analyzing and defining target $\rightarrow$ Efficiency (H5a) & $0.189(1.973)^{*}$ \\
\hline Setting program plans $\rightarrow$ Efficiency (H5b) & $0.218(2.293)^{* *}$ \\
\hline Operating and delivering service $\rightarrow$ Efficiency (H5c) & $0.228(2.403)^{* *}$ \\
\hline Tailored and integrated service $\rightarrow$ Efficiency (H5d) & $0.203(2.126)^{* *}$
\end{tabular}

${ }^{*}$ Significant at 0.05 level (2-tailed)

${ }^{*}$ Significant at 0.1 level (2-tailed)

This study fundamentally plans to recognize the effects of efficiency on effectiveness and the effects of effectiveness on the financial and social improvement of vulnerability. ANOVA results show significance at the 0.01 level with $F$ $=29.077(r$-square $=0.217)$ and $F=38.510(r$-square $=0.268)$. Both the effects of efficiency on effectiveness and effects of effectiveness on social welfare improvement and financial and social independence are significant at $\alpha=$ 0.01. Therefore, H6a and H6b are accepted (Table 7). 
Table 7. Relation of Efficiency and Effectiveness

\begin{tabular}{l|c}
\hline \multicolumn{1}{c|}{ Variables (Independent $\rightarrow$ dependent) } & Standardized Coefficient (t-value) \\
\hline Efficiency $\rightarrow$ Effectiveness (H6a) & $0.466(5.392)^{* * *}$ \\
\hline $\begin{array}{l}\text { Effectiveness } \rightarrow \text { social welfare improvement and financial \& social } \\
\text { independence (H6b) }\end{array}$ & $0.518(6.206)^{* * *}$ \\
${ }^{* * *}$ Significant at 0.01 level (2-tailed) &
\end{tabular}

\section{CONCLUSION}

The study attempts to discover the relationship between the efficiency and effectiveness of employment policy programs for vulnerable people by redefining and analyzing target groups, planning, operating and improving the program. This study finds that the definition and segmentation of vulnerable people is difficult, while the process would still help in setting the direction of the program and reflecting the needs and expectations of the program by recognizing appropriate target groups. The defined vulnerability can be addressed with social support for each group of vulnerable people. The survey result show that the definition of vulnerable people should include both the economic value such as household income and the social value of vulnerable groups such as the aged, the disabled, the homeless, and single parents. This study also concludes that tailored and integrated services to respond to fundamental vulnerabilities are necessary. For instance, aged people are no longer social dependents and the new concept of 'active aging' portrays them as an employable and willing-to-work group, together with pensions, health care and other welfare. In the case of disabled people, less severely disabled people have more possibilities than severely disabled people, so more segmented groups based on the degree of disability and more detailed program for each group should be designed. Furthermore, single parents expect different types of support as per gender of parents or ages of their children.

This study carried out in-depth interviews with seven field experts. Most interviewees agree that government promotion and campaigns would be better because their entities have smaller budgets and fewer channels for promotion and campaigning. The interviewees also state that they work hard at successful matching between job seekers and employers, but they realize the gaps of expectation between them. Therefore, it is required that job seekers improve their self-confidence and business attitudes and for employers to eliminate stereotype and prejudice and to understand possible hardships. The interviewees emphasize exploring and creating jobs because it would be ideal to connect from training to hiring. However, in reality, the job supply cannot meet the demand. All interviewees agree not only with the tailored and integrated service but also bring another aspect not only service integration, but also institutional integration and information integration. All interviewees emphasize the issue of beneficiaries of national basic livelihood because they would lose this status if they earn any income from employment, and it discourages them from re-entering into labor market.

The quantitative research of this study tests hypotheses with four major factors and subordinate factors based on the proposed model, subject to the perspectives of public officers. This study finds that hiring companies and selective supports are significant in redefining and analyzing targets, rather than defining the target groups for each program. Setting program plans, program contents, promotion and campaigns and funding are not as influential as operating bodies, processes and evaluation. Counseling and training are significant factors in increasing the efficiency of operations and delivery services. According to program improvement as the recommended service scheme, both tailored and integrated services are all significant to an increase in efficiency. Major factors including redefining and analyzing the target group; setting the program plan; operating and delivery; and program improvement all contribute to an increase in overall efficiency. This study concludes that the overall efficiency of the program improves the effectiveness of the program and finally supports welfare improvement and practical self-reliance socially and financially.

With more diverse research, innovative ways to approach, service operations and delivery are expected in order to provide efficient and tailored service. In the area of social welfare, IT technologies such as smart-phone application for transportation systems strengthen the accessibility of welfare benefits for vulnerable people. This study posits that creating an eligible labor market for vulnerable populations is also necessary. It has been criticized that the current feasible jobs for vulnerable people are simple labor, and that governmental work projects do not provide sustainable jobs. The interviews reveal that vulnerable people often have difficulties participating in employment support 
programs or job training because of their immediate needs such as food, housing, etc. Each category of vulnerable groups might face different obstacles and needs. Therefore, the fundamental mechanism of employment policy for vulnerable people is definitely not intended to push them into the completely competitive labor market. Vulnerable people have weak qualifications such as low education and social background in the competitive job market, so encouraging them to jump into the competitive market without support and protection would result in another possibility for them to be excluded from society. Balancing ongoing business profits and support for welfare consideration are a challenge. Delicate job creation and investment in the labor market for vulnerable people should proceed and people as consumers should purchase and use goods and services from vulnerable people without prejudice. All this effort can create more eligible jobs for vulnerable people.

This study has limitations. It was difficult to collect information, for both the qualitative and quantitative methods. For qualitative research, seeking an interview appointment was an obstacle. Most welfare or field workers have been overworked. Therefore sending preliminary interview guides and an approximate questionnaire was helpful recruiting interviewees and to avoid wasting interview time. Not only the interviews, but also conducting the survey met with a low response rate. The first e-mail survey request was sent from Qualtrics.com, but many government bodies block corporate or group mail as SPAM messages. Despite three reminder messages, 107 valid responses were available out of 1,279 public officers. Further studies might consider how eliminating inefficient factors improves the effectiveness of employment policy programs, as well as how small and medium enterprises (SMEs) can contribute to job creation and social inclusion for vulnerable populations. Further study of relationships between the power of job creation by SMEs and the portion of jobs available to vulnerable populations would contribute to a greater, more influential increase in the employment and social inclusion of vulnerable people.

\section{AUTHOR BIOGRAPHIES}

Eun Joo Lee received a Master's degree from the KDI School of Public Policy and Management.

Yoon C. Cho is a professor at the KDI School of Public Policy and Management. She has publications in the Journal of Business Research, Advanced in Consumer Research, and Journal of Business Economics Research, etc.

\section{REFERENCES}

Bang, H. N. and Kang, S. W. (2012). The objective definition of vulnerable group and the policies for employment and welfare, Seoul: Economic and Social Development Commission of Korea.

Blair, T. (1998). The Third Way: New Politics for the New Century. London: Fabian Society.

Blalock, A. B. (1999). "Evaluation Research and the Performance Management Movement: From Estrangement to Useful Integration?" Evaluation, 5(2), 117-149.

Bode, I., \& Sandvin, J. (2012). “The Many Rationales for Welfare-to-Work Regimes,” Journal of Comparative Social Work(2).

Cambridge University Press. (2015). Retrieved 03 05, 2014, from Cambridge Dictionaries Online, http://dictionary.cambridge.org/dictionary/british/populism

Caplan, B. (2001). "Rational Irrationality and the Microfoundations of Political Failure," Public Choice, 107(3-4), 311-331. '

Choi, M. H. and Jang, H. J. (2007). “A Study on the Factors of Satisfaction with Cafeteria Benefit Plan,” 16(4), $245-275$.

Choi, N. G., and Dinse, S. (2006). "Challenges and Opportunities of the Ageing Population: Social Work Education and Practice for Producive Aging," Educational Gerontology, 24(2), 159-173.

Connolly, M. and Smith, R. (2010). "Reforming Child Welfare: An Integrated Approach," Child Welfare, 89(3), 9-31.

Cook, K. (2012). "Social Support in Single Parents' Transition from Welfare to Work: Analysis of Qualitative Finidings," International Journal of Social Welfare, 21(4), 338-250.

Cooke, M. (2006). "Policy Changes and the Labour Force Participation of Older Workers: Evidence from Six Countries," Can Journal Aging, 25(4), 387-400.

Dostal, J. (2008). The Workfare Illusion: Re-examining the Concept and the British Case. Social Policy \& Administration, 42(1), 19-42.

Elder, C., \& Cobb, R. (1984). “Agenda-Building and the Politics of Aging,” Policy Studies Journal, 13(1), 115-129.

Engau, C. and Hoffmann, V. (2009). "Effects of Regulatory Uncertainty on Corporate Strategy—an Analysis of Firms' Responses to Uncertainty about Post-Kyoto Policy," Environmental Science \& Policy, 12(7), 766-777.

Esping-Anderson, G. (1990). The Three Worlds of Welfare Capitalism. Cambrige, UK: Policy Press.

Evers, A. and Guillemard, A.-M. (Eds.). (2012). Social Policy and Citizenship. Oxford: Oxford University Press.

Fahr, R. and Sunde, U. (2009), Did the Hartz Reforms Speed-Up the Matching Process? A Macro-Evaluation Using Empirical Matching Functions. German Economic Review, 10: 284-316. 
Flaskerud, J. and Winslow, B. (1998). “Conceptualizing Vulnerable Populations Health-Related Research,” Nursing Research, 47(2), pp. 69-78.

Giddens, A. (2013). The Third Way: The Renewal of Social Democracy. Cambridge: hn Wiley \& Sons.

Greve, B. (2009). "The labour market situation of disabled people in European countries and implementation of employment policies: a summary of evidence from country reports and research studies," Academic Network of European Disability Experts (ANED).

Han, J.W. (2014). “A Research on Effectiveness of Single-Parent Family Service: focusing on In-Depth Interview Analysis," PNU Journal of Women's Studies, 24(2), 159-195

Heinrich, C. J. (2002). "Outcomes-Base Performance Management in the Public Sector: Implications for Government Accountability and Effectiveness," Pulic Administration Review, 62(6), 712-725.

Hoefer, R., \& Midgley, J. (Eds.). (2006). International Perspectives on Welfare to Work Policy. New York: The Haworth Press.

Hwang, J. S., Nam, K. C., Byun, J. K., Jung, K. H., Huh, J. H., and Lee, I. J. (2007). "Participatory Governement Senior Citizen Work Project Evaluation and Next Government," the 9th Senior Citizen Employment Expert Forum, Seoul: Korea Labor Force Development Institute for the aged, 1-36.

Jagannathan, R. and Camasso, M. (2005). "Beyond Intention to Treat Analysis in Welfare-to-Work Studies: The Efficacy of Labor Force Attachement, Human Capital Investment and Comnined Strategies for Self-Sufficiency," Journal of Social Service Research, 31(4), 43-60.

Jeong, Y. R. (2010), “The Comparative Study of Workfare,” SAPA Spring Conference, Seoul: Seoul Association for Public Administration, 61-78.

Jung, E. H., Park, S. J., Kim, B. Y., Ahn, H. Y., Lee, K.Y., Jung, I. J. (2013). "Establishing a Preventive Welfare System and Integrated Case Management Program for Vulnerable Families, Families in cirsis, and Multicultural Families," Seoul: Korea Institute for Health and Social Affairs.

Lee, J. H., and Lee, D. R. (2013). "The Comparative Study on the agenda settting for the working poor: Cobb theoretical model," Chung-Ang Public Adminstrative Review, 27(2), 75-103.

Lee, J., Kim, I. H., Lee, S. K., Kim, D. H., Kim, N. S., Kim, S. Y. (2006). "Research on Improving the Supporting System for Experiential Environmental Education Programs Funded by Ministry of Environment," Environmental Education, 19(1), 30-42.

Lee, S.M., \& Kushner, J. (2008). "Single-Parent Families: The Role of Parent's and Child's Gender on Academic Achievement," Gender and Education, 6, 607-621

Levine, C. (2008). "Research Involving Economically Disadvantaged Participant" In E. Emanuel, C. Grady, R. Crouch, R. Lie, F. Miller, \& D. Wendler (Eds.), The Oxford Text of Clinical Research Ethics, New York: Oxford University Press.

Lindsey, E. (1998). "Service Providers' Perception of Factors that Help or Hinder Homeless Families." Journal of Contemporary Social Services, 79(2), 160-172.

Lynn, L. J. and Robichau, R. W. (2013). "Governance and Organisational Effectiveness: towards a Theory of Government Performance," Journal of Public Policy, 33(2), 201-228.

McCain, C. and Shorten, J. (2002). "Cataloging Efficiency and Effectiveness," Library resources \& technical services, 46(1), 2331.

Mihaiu, D. M., Opreana, A., \& Cristescu, M. P. (2010). "Efficiency, Effectiveness and Performance of the Public Sector," Romanian Journal of Economic Forcasting, 4, 132-147.

Moreira, A. (2002). “An Offer You Can't Refuse,” Workfare in International Perspectives in Lodemel and H. Trickey(eds). Journal of European Social Policy, 12(1), 83-85.

Nam, K. C. (2012). "How should we look at the issue of the homeless?" Welfare Trends, 164, 5-8.

Newman, J., Glendinning, C., and Hughes, M. (2008). "Beyond modernisation? Social care and the transformation of welfare governance," Journal of Social Policy, 37(4), 531-557.

Noh, D.M. (2006). "Study on Job Creation for the Hard-to-employ Populations,” Disability \& Employment, 16(1), pp. $115-146$.

OECD. (2012). Public Expenditure and Participant Stocks on LMP. Retrieved 03 02, 2015, from http://stats.oecd.org/Index.aspx?DataSetCode=LMPEXP

O’Higgins, N. (2001). Youth Unemployment and Employment Policy: a Global Perspective. ILO.

Patrick, R. (2011). Disabling or Enabling:The Extension of Work-related Conditionality to Disabled People. Social Policy and Society, 10(3), 309-320.

Pollit, C., Bathgate, K., Caulfield, J., Smullen, A., and Talbot, C. (2001). “Agency Fever? Analysis of an International Policy Fashion," Journal of Comparative Policy Analysis: Research and Practice, 3(3), 271-290.

Radey, M. and Wilkins, B. (2011). Short-Term Employment Services for Homeless Individuals: PErceptions from Stakeholders in a Community Partnership. Journal of Social Service Research, 37(1), 19-33.

Rector, R. (2012). “Obama's End Run on Welfare Reform, Part one: Understanding Workfare,” Backgrounder, 2730.

Ruof, M. (2004). "Vulnerabilitym Vulnerable populations and Policy," Kennedy Institute of Ethics Journal, 14(4), pp. 411-424.

Seidman, I. (2013). Interviewing as Qualitative Research, $4^{\text {th }}$ ed., New York: Teachers College Press.

Shier, M., Ghaham, J., and Jones, M. (2009). "Barriers to Employment as Experienced by Disabled People: a Qualitative Anaysis in Calgary and Regina, Canada," Disability \& Society, 24(1), 63-75.

Steel, R. (2005). “Actively Involving Marginalized and Vulnerable People in Research,” In L. Lowes, \& I. Hulatt, Involving 
Service Users in Health and Social Care Research (pp. 18-29). Abingdon, Oxfordshire: Routledge.

Stewart, K. (2009). "Employment and Wage Trajectoies for Mothers Entering Low-skilled Work: Evidence from the British Lone Parent Cohort," Social Policy \& Aministration, 43(5), 483-507.

Sweet, R. (2001). "Career Information, Guidance and Counselling Services: Policy Perspectives," Australian Journal of Career Development, 10(2), 11-14.

Taylor, P. (1994). "The Ageing Workforce: Employers' Attitudes towards Older People," Work Employment \& Society, 8(4), 569591.

Thomson, E., Hanson, T., and McLanahan, S. (1994). "Family Structure and Child Well-Being: Economic Resources vs. Parental Behaviors," Social Forces, 73(1), 221-242.

Walker, A. (2002). "A Strategy for Active Ageing,” International Social Security Review, 55(1), 121-139.

Walker, A. (2006). "Active Ageing in Employment: Its Meaning and Potential.," Asia-Pacific Review, 13(1), 78-93.

Wildavsky, A. (1973). "If Planning is Everything, Maybe it's Nothing," Policy Science, 4, 127-153.

Yang, C. H., Lee, S. A., Lee, K. M., Lee, H. H., and Cho, J. (2000). "The concept of productive welfare in Korea," Social Welfare Policy, 10, 181-199.

Yang, S. I. (2013). "An Analysis on the Conflict of Local Welfare Policy surrounding Selectivism and Universalism: Focused on the Free School Meals Policy of Seoul," The Korea Local Administration Review, 27(1), 125-153.

Yates, S. and Roulstone, A. (2013). "Social Policy and Transition to Training and Work for Disabled Young People in the United Kingdom: Neo-liberalism for Better and for Worse?” Disability \& Society, 28(4), 456-470. 


\section{NOTES}

